\title{
Higher Education and Public Good in East and West
}

\author{
Simon Marginson and Lili Yang
}

The 70th year of the IAU has been marked not only by the Covid-19 pandemic but by the geopolitical tension between the United States and China. After almost four decades of cooperation, which began in shared opposition to Soviet Russia and a shared interest in China's modernisation, the leaders of each country have become strident critics of the other. The escalating war of words has led to disruptions in trade, communications and visas and now threatens the vast and fruitful cooperation between universities and researchers.

Much is at stake. Many US universities are in China, such as Stanford with its state-of-the-art centre at Peking University and NYU with a branch campus in Shanghai. Chinese universities benefit from visits in both directions, from bench-marking using American partner templates and from the return of US-trained doctoral graduates. US-China links in science are focused on crucial areas like biomedicine and epidemiology, planetary science and ecology, engineering, materials, energy, cybernetics. In 2018, there were 55,382 science papers co-authored between the US and China, the largest country-to-country collaboration in world science, compared with 23,616 US-Germany papers and 10,664 Germany-France papers. Yet, researchers with Chinese names holding dual appointments are being prosecuted for revealing their US grant applications to colleagues in China. Some US politicians typecast all Chinese students and researchers as spies for the Communist Party of China (CPC). For many, academic freedom is simply incompatible with China's system. Meanwhile, there is pushback in China. Future openness in both directions is in doubt.

Across the US-China divide, universities have much in common. At the same time, they are nested in cultural traditions and political systems that are very different,

\footnotetext{
S. Marginson $(\varangle) \cdot$ L. Yang

University of Oxford, Oxford, UK

e-mail: simon.marginson@education.ox.ac.uk

L. Yang

e-mail: lili.yang@education.ox.ac.uk

(C) The Author(s) 2021 
including relations between universities and government or state. There are divergent ideas about the public responsibility of higher education institutions, the nature of academic duties and freedoms, and student learning and self-development. These differences are much older than the CPC's assumption of power in 1949.

Can East-West trust and cooperation be sustained and where necessary restored? Can universities maintain fulsome connections despite government sabre-rattling? This will depend on the extent to which the similarities and differences between East's and West's social, political and university systems are understood. Moreover, cooperation depends on a readiness in the US and elsewhere to acquire a better understanding of Chinese civilisation - and thus also of higher education in China. Chinese language, ideas and institutions are less well known in the US and Europe, than vice versa.

This article examines similarities and the differences between China and the US/UK through the lens of ideas about the public role of higher education - the contributions of universities beyond the economic benefits for graduates. This lens readily brings the national comparison into view. We consider not just current policies but key ideas in each tradition. The task is challenging because there are only a few concepts which are common to the two traditions.

\section{Anglo-American Tradition}

There are two fundamental differences between Chinese and English-speaking political systems. One concerns state power. The other is about the individual.

The western political system is rooted in the idea of division of powers. This has been the combined legacy of the post-Roman division between church and state, the autonomy of Italian medieval cities and the merchants in many countries, and the evolution of the law and later of electoral systems as being both outside direct executive authority and in a continuing relation with it. The medieval university also emerged as a semi-independent institution, incorporated in its own right and partly separated from the church that nurtured it and the states that tried to control it. Between the two larger powers of state and church, the university built a space for scholars and in later years for science. In modern times, national government has reasserted itself in higher education, but the partial autonomy of the university, famously codified in the Humboldt tradition in Germany, has survived.

Despite periodic attempts to establish absolute rule, from feudal monarchs to twentieth-century dictators, the western state is essentially a limited state and reverts to that default position. Arguably, the Anglo-American political systems, in which the state is habitually distrusted, liberty is defined as freedom from state coercion, and the market is primary in relation to equality and solidarity, are one extreme of the western tradition. In some European countries, the state is seen as synonymous with civil society whereas, in the English-speaking polities, civil society is positioned outside the state. In the US even the public university is understood to be primarily part of civil society and the market. 
The second difference between China and the West, especially the Englishspeaking West, is the normative primacy of the individual. Medieval culture imagined the self in a unique relation with God, and this morphed into the rights-bearing property-owning individual who stood alone, like John Proctor in Arthur Miller's The Crucible. Later, democratic reformers defined the right-bearing person as all adult men, then all adults. The western reading of individual and society has many variants but central to Anglo-American culture are the beliefs that the individual is separable from the society that provides her/him with conditions of existence, and self-realisation of the individual is the purpose of life. Individual liberty, within the 'private' sphere, takes priority over other social goods. Hence the essential role of higher education is to provide opportunities for individual fulfilment.

In mainstream economics, the atomised individual is associated with methodological individualism, 'a doctrine about explanation which asserts that all attempts to explain social (or individual) phenomena are to be rejected ... unless they are couched wholly in terms of facts about individuals' (Lukes 1973, 110). In higher education policy, the most influential manifestation of methodological individualism in economics is human capital theory (Becker 1964). In the framework, higher education produces portable qualities in individuals, occupational knowledge and skills, which in turn generate higher earnings and other economically defined benefits for those individuals. The larger contributions of universities to scientific knowledge, culture, health, civic education or better international relations are seen as 'externalities', marginal to the core purpose of individual benefits.

However, the outcome of the doctrines of the limited state and the absolute primacy of the individual is that important elements are not explained. What is the basis of human society? How do the atomised individuals cooperate outside of economic markets? For example, what is higher education's contribution to the public or common good? Economic theory's ideas of externalities and market 'spill-overs' are not sufficient to explain this.

Arguably, the insufficiency of Anglo-American ideas about the collective dimension of social life has fed into the ambiguity, if not confusion, associated with the term 'public' and the public/private distinction. The term 'public' takes at least three differing meanings.

The first meaning is the public/private dualism. 'Public' and 'private' are seen as two halves of a whole, mutually exclusive and opposed to each other so that the ratio between them is seen as determining. Using this idea, in the first instance, higher education is seen as either a public good or a private good. Here, two kinds of public/private dualisms are in use. One is the distinction between state or government ('public') and market, household or individual ('private'). The other is the distinction in economic theory between private goods produced in a market, and public goods that cannot be profitably produced in a market because their benefits are not confined to individuals and are financed by governments or philanthropy (Samuelson 1954).

In Anglo-American higher education, basic research is seen as an economic public good and so needs government funding. There is no consensus about teaching, which is variously understood as a private or public good. However, it is widely agreed that equal opportunity of individuals in higher education is a public good. Here, the 
public/private dual intersects with the second meaning of 'public', meaning inclusive social relations, access, open communications or democracy, as in terms 'the public', or 'public opinion'. This understanding of 'public' has its origins not in England but in eighteenth-century France and America. It is not opposed to 'private' or exclusive to the individual. Here, the broader public role of universities moves from margins to the mainstream. Universities are expected to prepare graduates as citizens for all social roles and not just for the economy.

This broader open public realm shades into the third meaning of 'public good' as the shared and universal welfare. However, in the Anglo-American world, a problem with the larger ideas of 'public' is that the term retains connotations of limited government. The term 'common good', which includes non-government community building activities as well as the legal public sector, has been suggested in place of 'public good' (Locatelli 2018).

\section{Chinese Tradition}

The norms of Chinese governance have older roots, dating back to the Western Zhou dynasty (1046-772 BCE). The largest influence is the Confucian social system. There the spheres of the individual, family, state and tianxia (all under heaven) are not seen as being arranged on the basis of a separation of powers and the partial autonomy of each sphere. Rather, each smaller sphere ( $\mathrm{si}$ ) is nested in the larger sphere (gong). Hence the person is seen as nested in the extended family or kin group, and the family in the state. The state is not a limited western state. It has a comprehensive mandate for order and prosperity and intervenes freely anywhere at will to further the collective good, tianxia weigong, a concept that is close to the 'public good' in the West.

In Imperial China, unlike in the West, the state was always supreme in relation to the military, merchants, towns or religion, though local villages mostly ran themselves. Higher education was established not as autonomous from church and state but as a branch of statecraft, training officials for government service. Under the Song and Ming dynasties (960-1644 AD,) it expanded to provide partly meritocratic opportunities to enter the gentry on a large scale.

The Confucian individual is not separate from society. She/he is a relational and role bearing individual. Compliance is achieved not primarily by state coercion but through shared values about right conduct established by education. Habits of selfcultivation and lifelong learning, the will to continually improve oneself, are installed early in the family. Confucianism values free will but distinguishes between the inner self-centred on moral autonomy and social action by the outer self. Persons are obliged to restrain from enacting their will if there are negative social consequences. Self-determination is absolute, but self-realisation is not.

There is no translation of the English terms public/private in Chinese, but the priority given to the larger unit ( $g$ ong) over the smaller unit ( $\mathrm{si}$ ) ensures the primacy of the collective and public over the individual and private. Where there was fundamental 
tension between public and private interests in Imperial China, the larger collective was supreme. This led to recurring arguments from scholars that the individual was insufficiently protected.

Confucian self-cultivation remains the cornerstone of personal development, but much has changed, especially since 1949. The authority of the family has declined though it is still important. The party-state continues the comprehensive state but reaches more effectively into village, workplace and household. Geographical and social mobility, entrepreneurship, consumption and mass higher education have all enhanced the agency of the individual.

Modern higher education combines western and Chinese features. Like the Imperial academies, it serves national development but its academic forms and disciplines have been closely influenced by Western and especially American examples. On the other hand, state-nested governance, with dual leadership by the university president and the party secretary, and the potent spirit of continuous self-improvement that animates both persons and institutions, are more traditional. Compared to many western universities, China's institutions are closely regulated in leader selection, curricula and student numbers. Yet, like western universities, they have corporate autonomy and a large measure of academic freedom in the sciences. Faculty shape their research and freely conduct foreign relations. China could not have become a global science powerhouse without disciplinary autonomy. On the other hand, the social sciences and the humanities are more politically constrained, and faculty in China do not engage in American-style freewheeling public commentary.

Although modern China has a history of courageous intellectuals, when central political control is tightened there is limited scope for the American idea of the university as a centre of public discussion in civil society. Faculty value the social responsibility and status entailed in their role. They understand academic freedom as positive, in terms of their potential to contribute, rather than as negative, freedom from the state. Chinese universities are expected to contribute to local economies and communities. Faculty provide expertise to government at all levels, perhaps even more than in the West. Professors are expected to be critical of government policy when this is merited. The difference is that such exchanges take place behind closed doors, inside the party-state rather than open public settings.

Other notions of 'public' have more resonance in China. In interviews reported by Tian and Liu (2019) some faculty draw on the western economic dualism of public/private to describe Chinese higher education as a 'quasi-public' good. Fees are charged, and corporate universities compete for students, resources and status. Though this might suggest a US-China convergence, important differences remain. The same research shows that all of faculty, university leaders and government officials identify universities with the state, seeing them as unequivocally 'public' in the sense of ownership, governance and mission. The regulated private sector is included within the ambit of this comprehensive 'public' domain.

Further, while in both the US and China higher education is valued to the extent it helps individuals to advance in social and economic terms, research on family and student attitudes in China (e.g. Chen 2020) finds that achieving good Confucian personhood is as important as maximising human capital. The two are not seen 
as necessarily in conflict. The stronger individualism that has developed in China passes through a social system in which self-improvement, family and contributing to society remain strong motivators. In American terms, people in China want higher education that is both more 'private' and just as 'public' as before, a double ambition sustained by both state policy and popular culture.

\section{Summary}

How then do the higher education systems compare? In both the individual is important. An attractive feature of China's system is that the student is nested in social context. What matters is not just private enrichment but also personal and social ethics. There is also a stronger sense of governmental responsibility, placing China closer to, say, the Nordic systems than to the US. But it is too easy for the state to dominate. The independent civil order is relatively weak, reducing the scope of the university as constructive critic. The US offers a richer potential for university engagement in civil society. However, the American state, potentially the corrective to inequality, is on the back foot, and methodological individualism in policy narrows university contributions to both individuals and society.

These similarities and differences colour the way each system sees the other. They are longstanding and will not disappear. The key is to understand them and work with them.

\section{References}

Becker, G. (1964). Human capital: A theoretical and empirical analysis with special reference to education. Chicago, IL: University of Chicago Press.

Chen, J. (2020). Values reconciliation: Politics and ethics of Confucian piety and overseas education. ( $\mathrm{PhD}$ dissertation). University of Cambridge Faculty of Education.

Locatelli, R. (2018). Education as a public and common good: Reframing the governance of education in a changing context. UNECSO Education Research and Foresight Working Papers, 22. Retrieved from: http://unesdoc.unesco.org/images/0026/002616/261614E.pdf (1.06.2020)

Lukes, S. (1973). Individualism. Oxford: Blackwell.

Samuelson, P. (1954). The pure theory of public expenditure. Review of Economics and Statistics, 36(4), 387-9.

Tian, L., \& Liu, N. (2019). Rethinking higher education in China as a common good. Higher Education, 77(4), 623-40.

Simon Marginson is Professor of Higher Education at the University of Oxford, Director of the ESRC/OFSRE Centre for Global Higher Education (CGHE), Joint Editor-in-Chief of the journal Higher Education, Professorial Associate of the Melbourne Centre for Study of Higher Education at the University of Melbourne, and Lead Researcher with the Higher School of Economics in Moscow.

Lili Yang is a doctoral researcher at Centre for Global Higher education, University of Oxford. In Lili's doctoral thesis, she explores the similarities and differences between notions of "pub- 
lic (good)" in Sinic and Anglo-American traditions, and the implications for higher education. Broadly, her research interests include higher education policy, higher education in East Asia, and international higher education.

Open Access This chapter is licensed under the terms of the Creative Commons Attribution 4.0 International License (http://creativecommons.org/licenses/by/4.0/), which permits use, sharing, adaptation, distribution and reproduction in any medium or format, as long as you give appropriate credit to the original author(s) and the source, provide a link to the Creative Commons license and indicate if changes were made.

The images or other third party material in this chapter are included in the chapter's Creative Commons license, unless indicated otherwise in a credit line to the material. If material is not included in the chapter's Creative Commons license and your intended use is not permitted by statutory regulation or exceeds the permitted use, you will need to obtain permission directly from the copyright holder. 